\title{
Digitoxin and its analogs as novel cancer therapeutics
}

\author{
Hosam A Elbaz ${ }^{1}$, Todd A Stueckle ${ }^{1,4}$, William Tse ${ }^{2}$, Yon Rojanasakul ${ }^{1,5^{*}}$ and Cerasela Zoica Dinu ${ }^{3,6^{*}}$
}

\begin{abstract}
A growing body of evidence indicates that digitoxin cardiac glycoside is a promising anticancer agent when used at therapeutic concentrations. Digitoxin has a prolonged half-life and a well-established clinical profile. New scientific avenues have shown that manipulating the chemical structure of the saccharide moiety of digitoxin leads to synthetic analogs with increased cytotoxic activity. However, the anticancer mechanism of digitoxin or synthetic analogs is still subject to study while concerns about digitoxin's cardiotoxicity preclude its clinical application in cancer therapeutics. This review focuses on digitoxin and its analogs, and their cytotoxicity against cancer cells. Moreover, a new perspective on the pharmacological aspects of digitoxin and its analogs is provided to emphasize new research directions for developing potent chemotherapeutic drugs.
\end{abstract}

\section{Introduction}

Cardiac glycosides (CGs) are a large family of chemical compounds found in several plants and animal species [1]. Plants containing CGs were used for more than 1500 years as diuretics, emetics, abortifacients, antineoplastics, and heart tonics [2]. In the 18th century, English physician and scientist William Withering discovered that a patient with congestive heart failure, "dropsy", improved after administering foxglove extract (Digitalis purpurea L.) [3]. Since then, many CGs have been isolated and their pharmacological effects have been tested; subsequently, CGs were used for treating congestive heart failure, cardiac arrhythmias, and atrial fibrillation $[4,5]$.

Generally, CGs share a common structural motif with a steroidal nucleus, a sugar moiety at position 3 (C3), and a lactone moiety at position 17 (C17) [1]. Figure 1 shows the common structural motif of CGs. The steroidal nucleus is the core structure of CG and is considered to be the active pharmacophoric moiety [6]. CGs also show an $A / B$ and $C / D$ cis-conformation that is different from mineralocorticoids, glycocorticoids, or sex hormones known to show trans-confirmation [6]. The presence of sugars at position 3 on the steroid ring significantly

\footnotetext{
* Correspondence: yrojan@hsc.wvu.edu; cerasela-zoica.dinu@mail.wvu.edu ${ }^{1}$ Department of Basic Pharmaceutical Sciences, West Virginia University, Morgantown, W, USA

${ }^{3}$ Department of Chemical Engineering, West Virginia University, Morgantown, W, USA

Full list of author information is available at the end of the article
}

affects the pharmacological profile of each glycoside $[7,8]$. Free aglycones, for instance, show faster and less complex absorption and metabolism compared to their glycosylated counterparts [7]. Additionally, the type of sugar attached to the steroidal nucleus changes the potency of CG compounds [8,9].

It is well established that CGs inhibit $\mathrm{Na}^{+} / \mathrm{K}^{+}$-ATPase and increases intracellular sodium ions [10]. The $\mathrm{Na}^{+} /$ $\mathrm{K}^{+}$-ATPase is a P-type pump that actively transports potassium ions inside and sodium ions outside cells in a 2:3 stoichiometry [11]. Such activity keeps intracellular sodium levels low, thus initiating and sustaining adequate electrochemical gradient across the plasma membrane [11]. Appropriate electrochemical gradient is essential for vital cellular processes such as ion homeostasis, neuronal communication, and apoptosis $[10,12]$. To maintain ion homeostasis after $\mathrm{Na}^{+} / \mathrm{K}^{+}$-ATPase inhibition by CGs, the cells have to restore intracellular sodium concentration to their basal levels by stimulating the $\mathrm{Na}^{+} / \mathrm{Ca}^{2+}$ exchange pump to extrude sodium ions out of the cell and introduce calcium ions into the cell [10]. This activity increases intracellular calcium ions and results in increased cellular phenomena such as calcium dependent signaling and myocardial contractility [5].

\section{Cardiac glycosides and their anticancer action}

A growing body of evidence suggests significant anticancer effects mediated by CGs. For instance, in the 8th century, CG plant extracts were used for treating malignant
C Biomed Central

() 2012 Elbaz et al; licensee BioMed Central Ltd. This is an Open Access article distributed under the terms of the Creative Commons Attribution License (http://creativecommons.org/licenses/by/2.0), which permits unrestricted use, distribution, and reproduction in any medium, provided the original work is properly cited. 


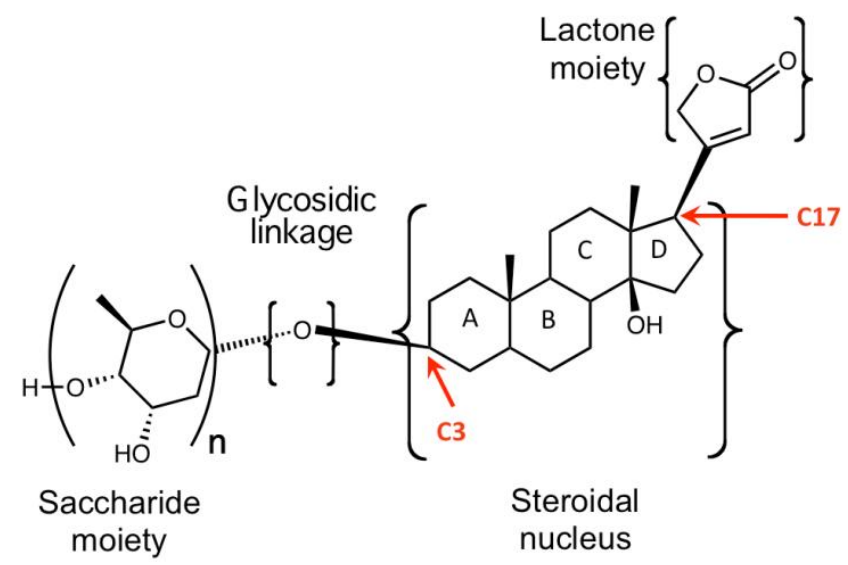

Figure 1 Structural characteristics of CGs. The common structural motif of a CG molecule is characterized by a steroidal nucleus, a lactone moiety at C17, and a saccharide moiety at C3 linked to the steroidal nucleus by a glycosidic linkage.

conditions [13]. An ancient Chinese remedy that employs an extract of Bufo bufo toad secretions contains several CGs and is still being used today for managing cancerous conditions [14-16]. Investigations in using CGs as anticancer drugs intensified in the 1960s $[17,18]$. Shiratori et al. examined the cytotoxicity of CGs in rodent cancer models and found inhibition of in vitro proliferation at concentrations that are relatively toxic to humans (0.1-10 $\mu \mathrm{M})$ [17]. A series of landmark epidemiological studies by Stenkvist et al. compared breast cancer tissue samples from women maintained on digitalis (a CG) for cardiac conditions to tissue samples from control patients [19]. This study found that women on digitalis therapy developed more benign forms of breast tumors when compared to control patients [19-22]. Additionally, patients on digitalis treatment showed a 9.6-time lower cancer recurrence rate compared to control patients, 5 years after mastectomy for primary tumor [21]. In 1984, Goldin et al. examined 127 cancer patients treated with digitalis [23]. While patients in the control group had 21 cancerrelated deaths, only one patient died in the digitalis group [23]. Twenty years later using follow-up data, Stenkvist et al. found that those patients on digitalis treatment showed significantly lower mortality rate than the control group [22]. Given the promising epidemiological results and the emergence of human cancer cell lines, several studies investigated the cytotoxic effect of different CGs on human cancer cells. Examples of the CGs of plant or animal origins that exhibit anticancer effects are shown in Table 1.

\section{Digitoxin: a well established CG}

Digitoxin is one of the few CGs that have been extensively studied and have a well-established clinical profile
$[67,68]$. Digitoxin is a cardiotonic drug with a narrow therapeutic window; thus, toxicity is a persistent concern whenever digitoxin is considered for therapy [69]. Cardiotoxicity is frequently encountered as the most significant toxicity following digitoxin's clinical administration [70,71]. However, digitoxin is perhaps one of the most promising anti-cancer CGs since it shows significant anticancer effect against several types of cancer including lung cancer, pancreatic cancer, leukemia, and breast cancer, all at therapeutic concentrations (see Table 1) $[18,31,58,68,72]$. Moreover, digitoxin has a prolonged half-life [69], which can potentially contribute to a less frequent and more stable pharmacokinetic profile in digitoxin-treated cancer patients. Such advantages qualify digitoxin for further laboratory investigations and clinical trials. However, to justify the anticancer clinical application of digitoxin, its anticancer mechanism ought to be clearly understood. Also, with the persistent concern about digitoxin's cardiotoxicity, further studies are needed to clarify the cytotoxic mechanism of digitoxin in cancer cells.

\section{Digitoxin and its anticancer mechanism}

To understand its anticancer mechanisms, initial research focused on the ability of digitoxin to inhibit $\mathrm{Na}^{+} / \mathrm{K}^{+}$ATPase pump at concentrations between $0.5-5 \mu \mathrm{M}$ $[5,10-12,73]$. Such inhibition can result in increased intracellular calcium via increased $\mathrm{Na}^{+} / \mathrm{Ca}^{2+}$ pump activity and subsequently induce apoptosis in cancer cells [74-76]. Figure $2 \mathrm{~A}$ shows how inhibiting the $\mathrm{Na}^{+} / \mathrm{K}^{+}$-ATPase pump causes an accumulation of intracellular sodium, thus perturbation of cellular ion homeostasis [5,10-12]. For the cells to restore ion homeostasis, the $\mathrm{Na}^{+} / \mathrm{Ca}^{2+}$ exchanger needs to be activated to export excess sodium 


\begin{tabular}{|c|c|c|c|c|}
\hline Compound & Structure and Natural Origin & Susceptible cancer types & $\mathrm{IC}_{50}$ Range & References \\
\hline Bufalin & Bufobufoga & $\begin{array}{l}\text { - Prostate cancer (PC3, DU145, and LNCaP cells) } \\
\text { - Leukemia (THP1, U937, and MOLT-3 cells) }\end{array}$ & $0.1-10 \mu \mathrm{M}$ & {$[14,15,24-28]$} \\
\hline Cinobufagin & Bufobufogargarizans & - Prostate cancer (PC3, DU145, and LNCaP cells) & $0.1-10 \mu \mathrm{M}$ & {$[14,15,24,25,27,28]$} \\
\hline Digitoxin & $\begin{array}{c}\text { Digitalis purpurea and } \\
\text { Digitalis lanata, } \\
\text { (Scrophulariaceae) }\end{array}$ & $\begin{array}{l}\text { - Prostate cancer (PC3, DU145, and LNCaP cells) } \\
\text { - Breast cancer (MCF-7 cells) } \\
\text { - Renal adenocarcinoma (TK-10 cells) } \\
\text { - Melanoma (UACC-62 cells) } \\
\text { - Leukemia (K-562 cells) } \\
\text { - Lung (A549 cells, and NCI-H460 cells) }\end{array}$ & $0.01-10 \mu \mathrm{M}$ & {$[9,29-40]$} \\
\hline Digoxin & $\begin{array}{c}\text { Digitalis purpurea and } \\
\text { Digitalis lanata, } \\
\text { (Scrophulariaceae) }\end{array}$ & $\begin{array}{l}\text { - Prostate cancer (PC3, DU145, and LNCaP cells) } \\
\text { - Cervical cancer (Hela cells) } \\
\text { - Lung (A549 cells, and NCI-H460 cells) }\end{array}$ & $0.1-10 \mu \mathrm{M}$ & {$[29-32,35,40,41]$} \\
\hline Oleandrin & $\begin{array}{l}\text { Neriu } \\
(\text { Apo }\end{array}$ & $\begin{array}{l}\text { - Prostate cancer (PC3, DU145, LNCaP) } \\
\text { - Leukemia (U-937, and HL-60 cells) } \\
\text { - Breast cancer (MCF-7) } \\
\text { - Lung } \\
\text { - Malignant Fibroblast (VA-13) } \\
\text { - Liver carcinoma (HepG2 cells) } \\
\text { - Pancreatic cancer (PANC-1 cells) }\end{array}$ & $0.1-1 \mu \mathrm{M}$ & {$[42-57]$} \\
\hline Ouabain & $\begin{array}{l}\text { Strophanthusgratus, } \\
\text { (Apocynaceae) }\end{array}$ & $\begin{array}{l}\text { - Prostate cancer (PC3, DU145, LNCaP) } \\
\text { - Breast cancer (MDA-MB-435scells) } \\
\text { - Lung (NCI-H460 cells) }\end{array}$ & $0.1-10 \mu \mathrm{M}$ & {$[2,29,30,32-35,40,46,58-62]$} \\
\hline Proscillaridin & $\begin{array}{l}\text { Urginea Maritime, } \\
\quad \text { (Liliaceae) }\end{array}$ & $\begin{array}{l}\text { - Breast cancer (MCF-7 cells) } \\
\text { - Fibroblasts }\end{array}$ & $30-100 \mathrm{nM}$ & {$[29,30,32,33,35,43,63-66]$} \\
\hline
\end{tabular}

to the extracellular space while importing calcium, which in turn causes an accumulation of intracellular calcium that mediates cellular events such as myocardial contractility, cytoskeleton remodeling, and apoptosis [5,10-12]. Interestingly, however, epidemiological studies have shown that digitoxin inhibits cancer cell viability at nanomolar concentrations (10-100 nM) [18,31,36,58]. This suggests that digitoxin exhibits a different mechanism for its anticancer effect than the one initially proposed.

In 2003, Xie et al. suggested that the signaling characteristics of $\mathrm{Na}^{+} / \mathrm{K}^{+}$-ATPase are distinct from the ion pumping activity [77]. It was shown that $\mathrm{Na}^{+} / \mathrm{K}$ ${ }^{+}$-ATPase signalosome is a multiple-protein signaling complex of 3 alpha $(\alpha)$ subunits and 2 beta $(\beta)$ subunits 

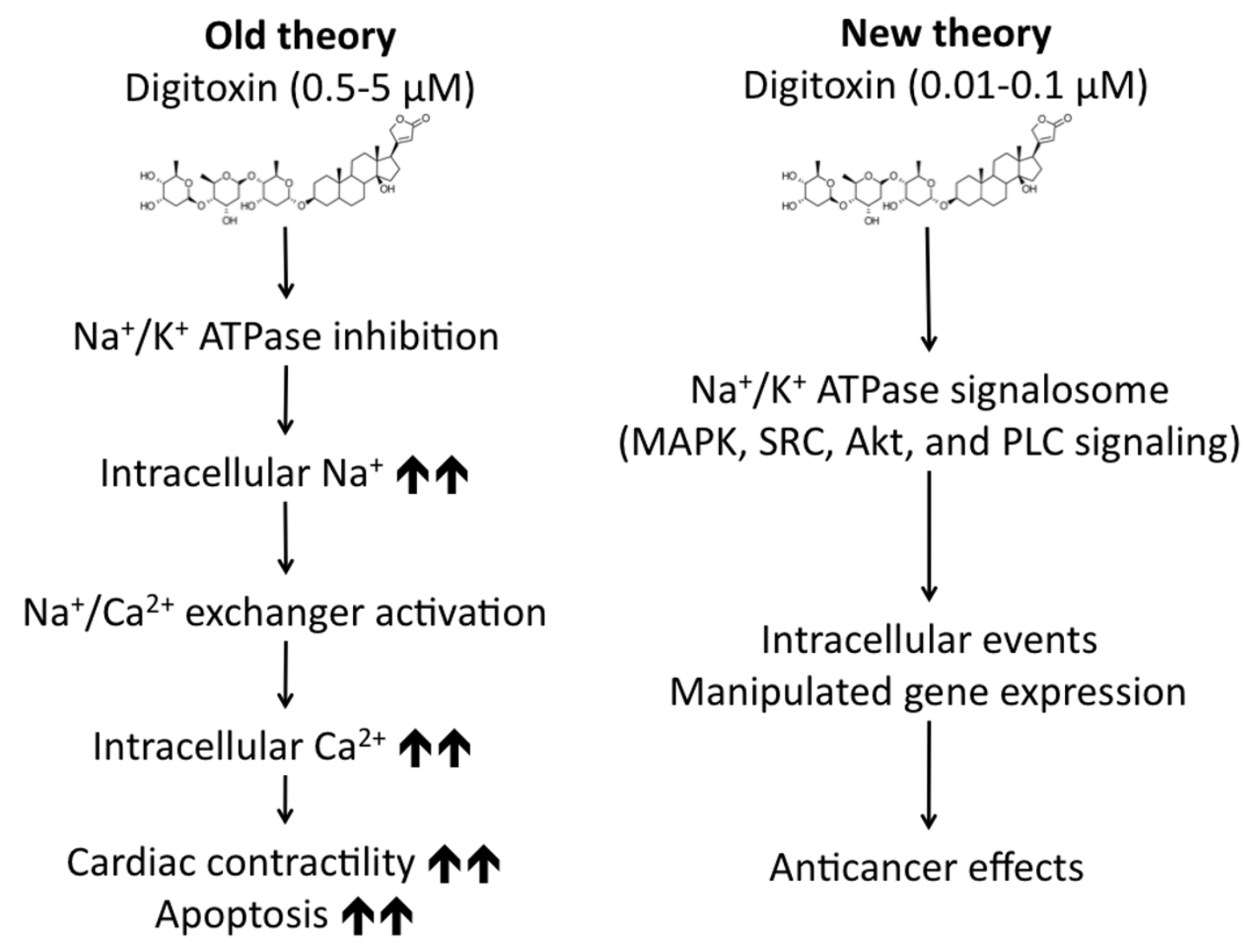

Figure 2 Effects of digitoxin on $\mathrm{Na}^{+} / \mathrm{K}^{+}$-ATPase at micromolar and nanomolar concentrations. (A) Old theory model summarizes the effect of digitoxin at 0.5-5 $\mu \mathrm{M}$ concentrations. (B) New theory model summarizes digitoxin's effect at 0.01-0.1 $\mu \mathrm{M}$ concentrations.

that controls cellular activities like apoptosis [78], cell proliferation [79], cell motility [80], and tight junctions [81]. Subsequently, it was proposed that digitoxin at nanomolar concentrations activates $\mathrm{Na}^{+} / \mathrm{K}^{+}$ATPase signalosome to transmit intracellular signals. Figure $2 \mathrm{~B}$ summarizes the intracellular effects of digitoxin upon binding to $\mathrm{Na}^{+} / \mathrm{K}^{+}$-ATPase at concentrations between 10-100 nM. Upon binding, digitoxin modulates the $\mathrm{Na}$ ${ }^{+} / \mathrm{K}^{+}$-ATPase protein complex activating the associated downstream signaling pathways, i.e., activation of several signaling cascades such as phospholipase C (PLC) signaling, mitogen-activated protein kinase (MAPK) signaling, phosphatidyl-inositol-3-kinase (PI3K) signaling, and Src kinase signaling.

The signaling cascades that are stimulated upon the interaction of digitoxin with $\mathrm{Na}^{+} / \mathrm{K}^{+}$-ATPase have mixed functions. For example, the MAPK signaling is mainly a proliferative and pro-survival signaling that can also be complemented by a pro-apoptotic signaling capability [82-88]. Src kinase signaling is a non-receptor tyrosine kinase that exhibits pro-survival as well as pro-apoptotic functions [89-97]. Therefore, digitoxin's ability to affect the downstream $\mathrm{Na}^{+} / \mathrm{K}^{+}$-ATPase signalosome is very complex. Such complexity, together with the digitoxin's narrow therapeutic window and its known cardiotoxicity, led to a slow progress in developing digitoxin as anticancer therapeutics $[1,2,18,98]$.

\section{Designing digitoxin analogs as anticancer agents}

Early on, it was suggested that a potential approach to circumvent digitoxin's cardiotoxicity is to design synthetic analogs that are either more effective or less toxic than digitoxin when used as anticancer agents $[8,99]$. Such analogs were designed by structural modifications of digitoxin's chemical entity. For example, using digitoxin as a template, Langenhan et al. developed MeON-neoglycosylation, a chemoselective method for glycorandomization that employs modifying the glycosidic bond that links the saccharide moiety to the core steroidal nucleus of digitoxin [99]. In 2008, Zhou and O'Doherty developed another method for modifying the glycosidic linkage of digitoxin using palladium-catalyzed glycosylation $[100,101]$. The O'Doherty analogs are characterized by an ether linkage between the saccharide moiety and the steroidal nucleus. 
As a result, novel synthetic digitoxin $\mathrm{O}$-glycoside analogs were synthesized $[9,100,101]$. Figure 3 shows the core structures of digitoxin analogs synthesized by Langenhan et al. and O'Doherty et al. respectively [99-101].

The differential potency and cytotoxic selectivity of digitoxin MeON-neoglycosides and digitoxin O-glycosides have been demonstrated in various cancer cell lines. For instance, Iyer et al. compared a library of digitoxin $\mathrm{MeON}$-neoglycosides and digitoxin $\mathrm{O}$-glycosides in a panel of 60 different cancer cell lines [9]. They showed that $\mathrm{O}$-glycosides are more potent anticancer agents when compared to $\mathrm{MeON}$-neoglycosides in a variety of cancer cell lines from leukemia, to lung, pancreatic and breast cancer cells. Additionally, the authors also show that the potency of the analogs depends on their sugar moiety with the monosaccharide analog being more potent than the di- and tri-saccharide analogs, respectively. Wang et al. used artificial O-monosaccharide analogs that they tested against a panel of 60 different cancer cell lines [37-39]. They identified three digitoxin monosaccharide analogs that showed significantly greater cytotoxic potential against non-small cell lung cancer (NSCLC) cells [37-39]. The most promising of these analogs, D6-MA, was subsequently evaluated for its anticancer mechanism by Elbaz et al. [36].

\section{Anticancer mechanism and selectivity of digitoxin and D6-MA analog}

Elbaz et al. showed that the D6-MA analog was 4-5 folds more potent than digitoxin in inhibiting cell proliferation, inducing cell cycle arrest and apoptosis in NSCLC cells [36]. The authors also showed that digitoxin and D6-MA exhibited significantly greater cytotoxicity against NSCLC when compared to both primary and non-tumorigenic lung epithelial lines. The selective cytotoxicity in lung cancer cells included G2/M phase arrest and apoptosis [36]. Moreover, digitoxin and D6-MA inhibited the expression of p53, cdc2, cyclin B1, survivin, and Chk1/2, critical genes/proteins for cell proliferation.

In order to explain the observed anticancer effect, it is postulated that digitoxin and D6-MA activate several transcriptional regulatory cascades via the $\mathrm{Na}^{+} / \mathrm{K}$ ${ }^{+}$-ATPase signalosome [61,62,77,102-107]. This suggested mechanism of selective cytotoxic effect may be associated with reduced expression of cell cycle regulatory proteins that are specifically overexpressed in cancer cells. Figure 4 illustrates how digitoxin regulates the expression of these cancer specific proteins.

The above suggested mechanism is supported by previous work showing that digitoxin inhibits AP-1 and NF$\kappa \mathrm{B}$ signaling through the $\mathrm{Na}^{+} / \mathrm{K}^{+}$-ATPase signalosome $[45,55,106,108-112]$. AP-1 is a transcription factor that promotes the expression of cell cycle regulatory proteins such as cdc2 and cyclinB1 [113-115]. Several studies have shown that cyclinB1 is essential for cell viability $[116,117]$. CyclinB1 and cdc2 are overexpressed in cancer cells [118-123] and form a complex with each other prior to mitosis. They catalyze chromatin condensation as well as nuclear envelope breakdown during mitosis [124,125]. The cyclinB1/cdc2 complex performs a rate limiting function in G2/M phase transition and protects mitotic cells from apoptosis by activating survivin. Survivin is a vital cell cycle regulatory protein known to be overexpressed in

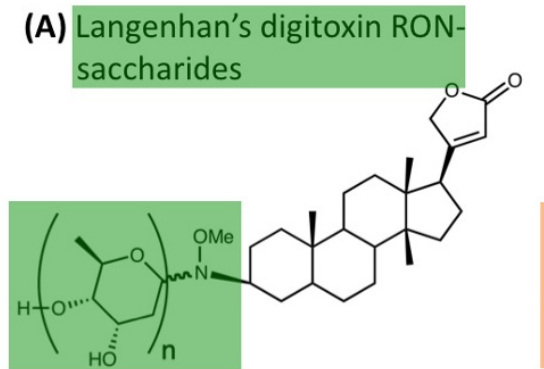

$\mathrm{n}=\mathbf{1}$; Digitoxin mono-MeONsaccharide

$\mathbf{n = 2 ;}$ Digitoxin di-MeON-saccharide $\mathbf{n = 3}$; Digitoxin tri-MeON-saccharide $n$

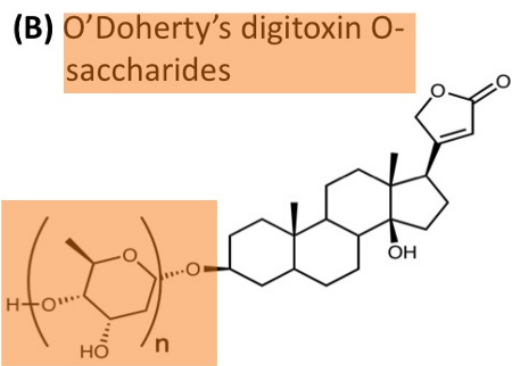

n=1; Digitoxin mono-O-saccharide $\mathbf{n = 2 ;}$ Digitoxin di-O-saccharide

$\mathrm{n}=3$; Digitoxin $\mathrm{n}=\alpha$-L-rhamnose; $D 6-M A$

Figure 3 The structure of novel digitoxin analogs. (A) The common structural motif of a neoglycoside molecule developed by Langenhan et al. and characterized by a tertiary amine bond linking the saccharide moiety to the steroidal nucleus. (B) The common structural motif of a digitoxin O-saccharide molecule developed by O'Doherty et al. and characterized by an ether bond linking the saccharide moiety to the steroidal nucleus. 


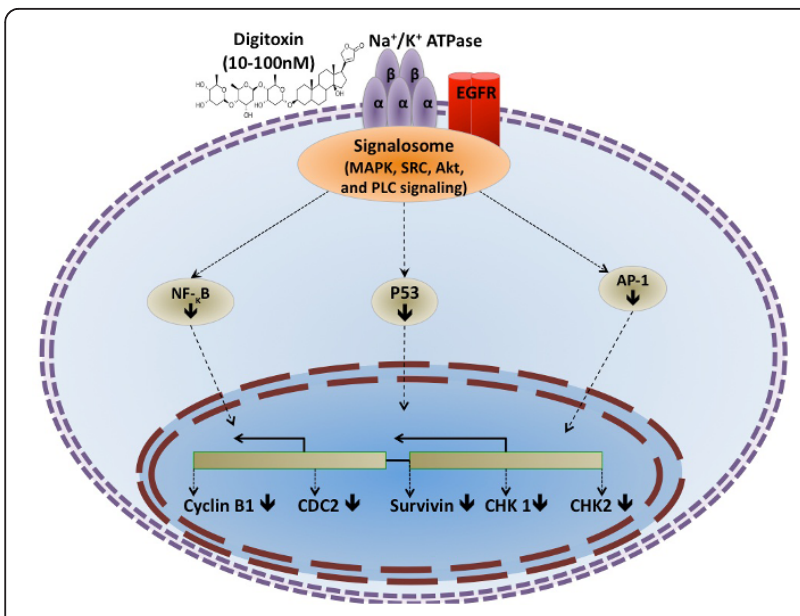

Figure 4 Digitoxin modulates $\mathrm{Na}^{+} / \mathrm{K}^{+}$-ATPase signalosome and inhibits the transcriptional activity of AP-1 and NF- $\kappa$ B which mediate the expression of cancer-specific cycle regulatory genes such as cyclin B1, cdc2, Chk1, Chk2, and surviving

different cancer types [126-131]. Survivin controls cell progression through mitosis by promoting the chromosomal passenger complex and regulating microtubule dynamics [132-135]. Additionally, survivin regulates the mitotic spindle checkpoint [136-139]. Several studies suggest survivin downregulation as a biomarker for mitotic catastrophe [140-142]. Also, NF- $\kappa$ B transcription factor regulates the expression of cell cycle regulatory proteins such as survivin [143]. Thus, by inhibiting both AP-1 and $\mathrm{NF}-\kappa \mathrm{B}$ signaling, digitoxin and D6-MA potentially inhibit the expression of cdc2, cyclin B1, survivin and Chk1/2, as shown in Figures 2 and 4. Moreover, the association of cyclin B1/cdc2 complex with survivin indicates that the complex is crucial for G2/M phase transition and cell viability, and inhibiting its expression by both digitoxin and D6-MA could potentially explain the selective cytotoxicity of these compounds towards cancer cells. Since inhibiting Chk $1 / 2$ typically elicits checkpoint abrogation and uncontrolled cell cycle progression abolished cell viability [144-146], a potential alternative mechanism of digitoxin and D6-MA's cytotoxicity may be their ability to cause checkpoint abrogation. It is unclear, however, how digitoxin and D6-MA inhibit checkpoint kinase proteins in cancer cells. Distinguishing between CG-induced cell cycle arrest and/or checkpoint abrogation will improve our understanding on how CGs including digitoxin and its analogs exert their anti-proliferative/cell death effect.

\section{Conclusions and outlook}

Digitoxin and D6-MA strongly modulate cell cycle machinery through the $\mathrm{Na}^{+} / \mathrm{K}^{+}$-ATPase signalosome in a manner that significantly undermines cell viability (Figure 4). However, several questions remain unanswered regarding their mechanistic control of cancer cell cycle.
Delineating the mechanism of cell cycle arrest and selectivity of digitoxin and its analogs are particularly interesting. First, it will improve our understanding of how digitoxin and its analogs cause G2/M phase arrest in cancer cells. Second, it will help identify novel p53-independent therapeutic targets to mediate cancer cell death. Since many cancer types develop resistance to chemotherapy by reducing p53 expression and signaling [158-168], identifying p53-independent therapeutic targets will contribute to the development of new and more effective cancer treatments by circumventing p53 related resistance mechanisms. Third, detailing how digitoxin and D6-MA inhibit survivin expression in cancer cells will improve our understanding on how the drugs cause G2/M phase arrest and apoptosis. Last, dissecting the inhibitory effects of these compounds on survivin and p53 expression in cancer cells would explore whether and how the compounds induce mitotic catastrophe. Answering these questions will elevate our understanding on the antineoplastic mechanism of CGs at therapeutically relevant concentrations, and develop new and more effective cancer treatments [147].

\section{Disclaimer}

Research findings and conclusions are those of the authors and do not necessarily represent the views of the National Institute for Occupational Safety and Health.

\section{Acknowledgements}

This work is supported by the NIH grants R01-HL076340, GM090259, GM088839 and the NSF grant EPS-1003907.

\section{Author details}

${ }^{1}$ Department of Basic Pharmaceutical Sciences, West Virginia University, Morgantown, WV, USA. ${ }^{2}$ Mary Babb Randolph Cancer Center, West Virginia University, Morgantown, WV, USA. ${ }^{3}$ Department of Chemical Engineering, West Virginia University, Morgantown, WV, USA. ${ }^{4}$ National Institute for Occupational Safety and Health, Morgantown, WV, USA. ${ }^{5}$ Department of Basic Pharmaceutical Sciences, West Virginia University, PO Box 9530, 1 Medical Center Drive, Morgantown, WV 26506, USA. 'Department of Chemical Engineering, West Virginia University, College of Engineering and Mineral Resources, PO Box 6102, ESB 445, Morgantown, WV 26506, USA.

\section{Authors' contributions}

HAE drafted the original manuscript; TAS and WT coordinated and helped to draft the manuscript. YR and CZD have been involved in revising the manuscript critically for its scientific content and have given final approval of the version to be published. All the authors read and approved the final manuscript.

\section{Competing interests}

The authors declare that they have no competing interests.

Received: 28 February 2012 Accepted: 5 April 2012

Published: 5 April 2012

\section{References}

1. Prassas I, Diamandis EP: Novel therapeutic applications of cardiac glycosides. Nat Rev Drug Discov 2008, 7(11):926-935. 
2. Newman RA, Yang P, Pawlus AD, Block Kl: Cardiac Glycosides as Novel Cancer Therapeutic Agents. Mol Interv 2008, 8(1):36-49.

3. Huxtable RJ: The Erroneous Pharmacology of a Cat. Mol Interv 2001, 1(2):75-77.

4. Gheorghiade M, van Veldhuisen DJ, Colucci WS: Contemporary Use of Digoxin in the Management of Cardiovascular Disorders. Circulation 2006, 113(21):2556-2564

5. Rahimtoola SH, Tak T: The use of digitalis in heart failure. Curr Probl Cardiol 1996, 21(12):781-853.

6. Schonfeld $W$ : The lead structure in cardiac glycosides is 5 [beta], 14 [beta]androstane-3[beta]14-diol. Naunyn Schmiedebergs Arch Pharmacol 1985, 329:414-426.

7. Melero $C P$, Medardea $\mathrm{M}$, Feliciano AS: A short review on cardiotonic steroids and their aminoguanidine analogues. Molecules 2000, 5:51-81.

8. Langenhan JM, Peters NR, Guzei IA, Hoffmann M, Thorson JS: Enhancing the anticancer properties of cardiac glycosides by neoglycorandomization. Proc Natl Acad Sci USA 2005, 102(35):12305-12310.

9. Iyer AKV, Zhou M, Azad N, Elbaz H, Wang L, Rogalsky DK, Rojanasakul Y, O'Doherty GA, Langenhan JM: A Direct Comparison of the Anticancer Activities of Digitoxin MeON-Neoglycosides and O-Glycosides: Oligosaccharide Chain Length-Dependent Induction of Caspase-9Mediated Apoptosis. ACS Med Chem Lett 2010, 1(7):326-330.

10. Barry W, Hasin Y, Smith T: Sodium pump inhibition, enhanced calcium influx via sodium-calcium exchange, and positive inotropic response in cultured heart cells. Circ Res 1985, 56(2):231-241.

11. Kaplan JH: Biochemistry of Na, K-ATPase. Annu Rev Biochem 2002, 71:511-535.

12. Kaplan JG: Membrane cation transport and the control of proliferation of mammalian cells. Annu Rev Physiol 1978, 40:19-41.

13. Brewer H: Historical perspectives on health. J R Soc Promot Health 2004, 124(4):184-187.

14. Watabe M, Masuda Y, Nakajo S, Yoshida T, Kuroiwa Y, Nakaya K: The Cooperative Interaction of Two Different Signaling Pathways in Response to Bufalin Induces Apoptosis in Human Leukemia U937 Cells. J Biol Chem 1996, 271(24):14067-14073.

15. Yeh JY, Huang WJ, Kan SF, Wang PS: Effects of bufalin and cinobufagin on the proliferation of androgen dependent and independent prostate cancer cells. Prostate 2003, 54(2):112-124.

16. Han KQ: Anti-tumor activities and apoptosis-regulated mechanisms of bufalin on the orthotopic transplantation tumor model of human hepatocellular carcinoma in nude mice. World I Gastroenterol 2007, 13:3374-3379

17. Shiratori O: Growth inhibitory effect of cardiac glycosides and aglycones on neoplastic cells: in vitro and in vivo studies. Gann 1967, 58(6):521-528.

18. López-Lázaro M: Digitoxin as an anticancer agent with selectivity for cancer cells: possible mechanisms involved. Expert Opin Ther Targets 2007, 11(8):1043-1053.

19. Stenkvist B: Cardiac glycosides and breast cancer. Lancet 1979, 1:563.

20. Stenkvist B: Evidence of a modifying influence of heart glucosides on the development of breast cancer. Anal Quant Cytol 1980, 2:49-54

21. Stenkvist B: Cardiac glycosides and breast cancer, revisited. N Engl J Med 1982, 306:484.

22. Stenkvist B: Is digitalis a therapy for breast carcinoma? Oncol Rep 1999, 6:493-496

23. Goldin AG, Safa AR: Digitalis and cancer. Lancet 1984, 1:1134.

24. Hashimoto S, Jing Y, Kawazoe N, Masuda Y, Nakajo S, Yoshida T, Kuroiwa Y, Nakaya K: Bufalin reduces the level of topoisomerase II in human leukemia cells and affects the cytotoxicity of anticancer drugs. Leuk Res 1997, 21(9):875-883.

25. Jing Y: Selective inhibitory effect of bufalin on growth of human tumor cells in vitro: association with the induction of apoptosis in leukemia HL-60 cells. Jpn J Cancer Res 1994, 85:645-651.

26. Kamano Y, Kotake A, Hashima H, Inoue M, Morita H, Takeya K, Itokawa H, Nandachi N, Segawa T, Yukita A, et al: Structure-cytotoxic activity relationship for the toad poison bufadienolides. Bioorg Med Chem 1998, 6(7):1103-1115.

27. Kawazoe N, Watabe M, Masuda Y, Nakajo S, Nakaya K: Tiam1 is involved in the regulation of bufalin-induced apoptosis in human leukemia cells. Oncogene 1999, 18:2413-2421.

28. Masuda Y: Bufalin induces apoptosis and influences the expression of apoptosis-related genes in human leukemia cells. Leuk Res 1995, 19:549-556.
29. Bielawski K, Winnicka K, Bielawska A: Inhibition of DNA topoisomerases I and II, and growth inhibition of breast cancer MCF-7 cells by ouabain, digoxin and proscillaridin A. Biol Pharm Bull 2006, 29(7):1493-1497.

30. Johansson S, Lindholm P, Gullbo J, Larsson P, Bohlin L, Claeson P. Cytotoxicity of digitoxin and related cardiac glycosides in human tumor cells. Anti-Cancer Drugs 2001, 12(5):475-483.

31. Lopez-Lazaro M, Pastor N, Azrak SS, Ayuso MJ, Austin CA, Cortes F: Digitoxin inhibits the growth of cancer cell lines at concentrations commonly found in cardiac patients. J Nat Prod 2005, 68(11):1642-1645.

32. Winnicka K, Bielawski K, Bielawska A, Miltyk W: Apoptosis-mediated cytotoxicity of ouabain, digoxin and proscillaridin $A$ in the estrogen independent MDA-MB-231 breast cancer cells. Arch Pharm Res 2007, 30:1216-1224.

33. Winnicka K, Bielawski K, Bielawska A, Miltyk W: Dual effects of ouabain, digoxin and proscillaridin $A$ on the regulation of apoptosis in human fibroblasts. Nat Prod Res 2010, 24(3):274-285.

34. Yeh JY, Huang WJ, Kan SF, Wang PS: Inhibitory effects of digitalis on the proliferation of androgen dependent and independent prostate cancer cells. J Urol 2001, 166(5):1937-1942.

35. Zhang HF, Qian DZ, Tan YS, Lee K, Gao P, Ren YR, Rey S, Hammer H, Chang D, Pili R, et al: Digoxin and other cardiac glycosides inhibit HIF-1 alpha synthesis and block tumor growth. Proc Natl Acad Sci USA 2008, 105(50):19579-19586

36. Elbaz HA, Stueckle TA, Wang H-YL, O'Doherty G, Lowry DT, Sargent LM, Wang L, Dinu CZ, Rojanasakul Y: Digitoxin and a synthetic monosaccharide analog inhibit cell viability in lung cancer cells. Toxicology and Applied Pharmacology 2012, 258(1):51-60.

37. Wang H-YL, Rojanasakul Y, O,ÄôDoherty GA: Synthesis and Evaluation of the a-d-/a-I-Rhamnosyl and Amicetosyl Digitoxigenin Oligomers as Antitumor Agents. ACS Med Chem Lett 2011, 2(4):264-269.

38. Wang H-YL, Wu B, Zhang Q, Kang S-W, Rojanasakul Y, O,ÄôDoherty GA: C5'Alkyl Substitution Effects on Digitoxigenin a-I-Glycoside Cancer Cytotoxicity. ACS Med Chem Lett 2011, 2(4):259-263.

39. Wang H-YL, Xin W, Zhou M, Stueckle TA, Rojanasakul Y, O'Doherty GA: Stereochemical Survey of Digitoxin Monosaccharides. ACS Med Chem Lett 2010, 2(1):73-78.

40. Wang Z, Zheng M, Li Z, Li R, Jia L, Xiong X, Southall N, Wang S, Xia M, Austin CP, et al: Cardiac Glycosides Inhibit p53 Synthesis by a Mechanism Relieved by Src or MAPK Inhibition. Cancer Res 2009, 69(16):6556-6564.

41. Winnicka K, Bielawski K, Bielawska A, Miltyk W: Dual effects of ouabain, digoxin and proscillaridin $\mathrm{A}$ on the regulation of apoptosis in human fibroblasts. Nat Prod Res 2010, 24(3):274-285.

42. Afaq F, Saleem M, Aziz MH, Mukhtar H: Inhibition of 12-Otetradecanoylphorbol-13-acetate-induced tumor promotion markers in CD-1 mouse skin by oleandrin. Toxicol Appl Pharmacol 2004, 195(3):361-369.

43. Felth J, Rickardson L, Rosen J, Wickstrom M, Fryknas M, Lindskog M, Bohlin L, Gullbo J: Cytotoxic Effects of Cardiac Glycosides in Colon Cancer Cells, Alone and in Combination with Standard Chemotherapeutic Drugs. J Nat Prod 2009, 72(11):1969-1974.

44. Gupta RS, Chopra A, Stetsko DK: Cellular basis for the species differences in sensitivity to cardiac glycosides (digitalis). J Cell Physiol 1986, 127(2):197-206.

45. Manna SK, Sah NK, Newman RA, Cisneros A, Aggarwal BB: Oleandrin suppresses activation of nuclear transcription factor-kappa $B$, activator protein-1, and c-Jun NH2-terminal kinase. Cancer Res 2000, 60(14):3838-3847.

46. McConkey DJ, Lin Y, Nutt LK, Ozel HZ, Newman RA: Cardiac glycosides stimulate $\mathrm{Ca} 2+$ increases and apoptosis in androgen-independent, metastatic human prostate adenocarcinoma cells. Cancer Res 2000, 60(14):3807-3812.

47. Nasu S, Milas L, Kawabe S, Raju U, Newman RA: Enhancement of radiotherapy by oleandrin is a caspase-3 dependent process. Cancer Lett 2002, 185(2):145-151.

48. Newman RA: Oleandrin-mediated oxidative stress in human melanoma cells. J Exp Ther Oncol 2006, 5:167-181.

49. Newman RA, Kondo Y, Yokoyama T, Dixon S, Cartwright C, Chan D, Johansen M, Yang P: Autophagic cell death of human pancreatic tumor cells mediated by oleandrin, a lipid-soluble cardiac glycoside. Integr Cancer Ther 2007, 6:354-364. 
50. Pathak S, Multani AS, Narayan S, Kumar V, Newman RA: AnvirzelTM, an extract of Nerium oleander, induces cell death in human but not murine cancer cells. Anti-Cancer Drugs 2000, 11(6):455-463.

51. Raghavendra PB, Sreenivasan Y, Manna SK: Oleandrin induces apoptosis in human, but not in murine cells: Dephosphorylation of Akt, expression of FasL, and alteration of membrane fluidity. Mol Immunol 2007, 44(9):2292-2302

52. Schoner W, Scheiner-Bobis G: Endogenous and exogenous cardiac glycosides: their roles in hypertension, salt metabolism, and cell growth. Am J Physiol Cell Physiol 2007, 293(2):C509-C536.

53. Smith JA, Madden T, Vijjeswarapu M, Newman RA: Inhibition of export of fibroblast growth factor-2 (FGF-2) from the prostate cancer cell lines PC3 and DU145 by Anvirzel and its cardiac glycoside component, oleandrin. Biochem Pharmacol 2001, 62(4):469-472

54. Sreenivasan $Y$, Raghavendra PB, Manna SK: Oleandrin-mediated expression of fas potentiates apoptosis in tumor cells. J Clin Immunol 2006, 26(4):308-322.

55. Sreenivasan $Y$, Sarkar A, Manna SK: Oleandrin suppresses activation of nuclear transcription factor-kappa B and activator protein-1 and potentiates apoptosis induced by ceramide. Biochem Pharmacol 2003, 66(11):2223-2239.

56. Wang XM, Plomley JB, Newman RA, Cisneros A: LC/MS/MS analyses of an oleander extract for cancer treatment. Anal Chem 2000, 72(15):3547-3552.

57. Yang PY, Menter DG, Cartwright C, Chan D, Dixon S, Suraokar M, Mendoza G, Llansa N, Newman RA: Oleandrin-mediated inhibition of human tumor cell proliferation: importance of $\mathrm{Na}$, K-ATPase alpha subunits as drug targets. Mol Cancer Ther 2009, 8(8):2319-2328.

58. Kometiani $P$, Liu L, Askari A: Digitalis-Induced Signaling by $\mathrm{Na}+/ \mathrm{K}+$ -ATPase in Human Breast Cancer Cells. Mol Pharmacol 2005, 67(3):929-936.

59. Lawrence TS: Ouabain sensitizes tumor cells but not normal cells to radiation. Int J Radiat Oncol Biol Phys 1988, 15(4):953-958.

60. Winnicka K, Bielawski K, Bielawska A, Surazy $\approx$ Ñski A: Antiproliferative activity of derivatives of ouabain, digoxin and proscillaridin $A$ in human MCF-7 and MDA-MB-231 breast cancer cells. Biol Pharm Bull 2008, 31(6):1131-1140

61. Xie Z, Kometiani P, Liu J, Li J, Shapiro Jl, Askari A: Intracellular reactive oxygen species mediate the linkage of $\mathrm{Na}+/ \mathrm{K}+-$ ATPase to hypertrophy and its marker genes in cardiac myocytes. J Biol Chem 1999, 274(27):19323-19328.

62. Xu J-W, Jin R-M, Wang Y-R, Lin W, Meng B: Effects of ouabain at different concentrations on growth of leukemia cells. Zhongguo Dang Dai Er Ke Za Zhi 2009, 11(4):259-262.

63. Contreras RG, Flores-Maldonado C, Lázaro A, Shoshani L, Flores-Benitez D, Larré I, Cereijido M: Ouabain Binding to $\mathrm{Na}+/ \mathrm{K}+$-ATPase Relaxes Cell Attachment and Sends a SpecificSignal (NACos) to the Nucleus. $J$ Membr Biol 2004, 198(3):147-158

64. Johansson S, Lindholm P, Gullbo J, Larsson R, Bohlin L, Claeson P: Cytotoxicity of digitoxin and related cardiac glycosides in human tumor cells. Anti-Cancer Drugs 2001, 12(5):475-483.

65. Schneider R: Proscillaridin A immunoreactivity: its purification, transport in blood by a specific binding protein and its correlation with blood pressure. Clin Exp Hypertens 1998, 20:593-599.

66. Winnicka K, Bielawski K, Bielawska A, Surazynski A: Antiproliferative activity of derivatives of ouabain, digoxin and proscillaridin a in human MCF-7 and MDA-MB-231 breast cancer cells. Biol Pharm Bull 2008,

31(6):1131-1140

67. Belz GG: Breithaupt-GrVJgler K, Osowski U: Treatment of congestive heart failure-current status of use of digitoxin. Eur J Clin Invest 2001, 31(Suppl 2):10-17.

68. Castle MC: Pharmacokinetics of digoxin and digitoxin in humans. Eastern virginia med sch/med col hamp rd 1977.

69. BøHMER T, RøSETH A: Prolonged digitoxin half-life in very elderly patients. Age Ageing 1998, 27(2):222-224.

70. Smith TW: Digitalis toxicity: epidemiology and clinical use of serum concentration measurements. Am J Med 1975, 58(4):470-476.

71. Williams JF Jr, Potter RD, Mathew B: Effects of arrhythmia-producing concentrations of digitoxin on mechanical performance of cat myocardium. Am Heart J 1983, 105(1):21-25

72. Haux J: Digitoxin is a potential anticancer agent for several types of cancer. Med Hypotheses 1999, 53(6):543-548.
73. Schatzmann HJ, Rass B: Inhibition of the active Na-K-transport and Na-Kactivated membrane ATP-ase of erythrocyte stroma by ouabain. Helv Physiol Pharmacol Acta 1965, 65:C47-C49.

74. Chang HT, Huang JK, Wang JL, Cheng JS, Lee KC, Lo YK, Liu CP, Chou KJ, Chen WC, Su W, et al: Tamoxifen-induced increases in cytoplasmic free Ca-2+ levels in human breast cancer cells. Breast Cancer Res Treat 2002, 71(2):125-131.

75. Koumura T, Nakamura C, Nakagawa Y: Role of calcium-induced mitochondrial hydroperoxide in induction of apoptosis of RBL2H3 cells with eicosapentaenoic acid treatment. Free Radic Res 2005, 39(10):1083-1089.

76. Pigozzi D, Tombal B, Ducret T, Vacher P, Gailly P: Role of store-dependent influx of $\mathrm{Ca} 2+$ and efflux of $\mathrm{K}+$ in apoptosis of $\mathrm{CHO}$ cells. Cell Calcium 2004, 36(5):421-430.

77. Xie Z, Cai T: Na+/K + ATPase-Mediated Signal Transduction: From Protein Interaction to Cellular Function. Mol Interv 2003, 3(3):157-168.

78. Wang XQ: Apoptotic insults impair $\mathrm{Na}+\mathrm{K}+-$ ATPase activity as a mechanism of neuronal death mediated by concurrent ATP deficiency and oxidant stress. J Cell Sci 2003, 116:2099-2110.

79. Liu L, Abramowitz J, Askari A, Allen JC: Role of caveolae in ouabaininduced proliferation of cultured vascular smooth muscle cells of the synthetic phenotype. Am J Physiol Heart Circ Physiol 2004, 287: H2173-H2182.

80. Barwe SP: Novel role for $\mathrm{Na}, \mathrm{K}$-ATPase in phosphatidylinositol 3-kinase signaling and suppression of cell motility. Mol Biol Cell 2005, 16:1082-1094.

81. Larre I, Lazaro A, Contreras RG, Balda MS, Matter K, Flores-Maldonado C, Ponce A, Flores-Benitez D, Rincon-Heredia R, Padilla-Benavides T, et al: Ouabain modulates epithelial cell tight junction. Proc Natl Acad Sci 2010, 107(25):11387-11392.

82. Bulavin DV, Fornace AJ Jr: p38 MAP kinase's emerging role as a tumor suppressor. Adv Cancer Res 2004, 92:95-118.

83. Cagnol S, Chambard J-C: ERK and cell death: mechanisms of ERK-induced cell death-apoptosis, autophagy and senescence. FEBS J 2009, 277(1):2-21.

84. de Paula RM, Lamb TM, Bennett L, Bell-Pedersen D: A connection between MAPK pathways and circadian clocks. Cell Cycle 2008, 7(17):2630-2634.

85. Gotoh I, Nishida E: Signal transductions by the MAP kinase cascades. Nippon Rinsho 1998, 56(7):1779-1783.

86. Han J, Sun P: The pathways to tumor suppression via route p38. Trends Biochem Sci 2007, 32(8):364-371.

87. Keyse SM: Dual-specificity MAP kinase phosphatases (MKPs) and cancer Cancer Metastasis Rev 2008, 27(2):253-261.

88. Khavari TA, Rinn J: Ras/Erk MAPK signaling in epidermal homeostasis and neoplasia. Cell Cycle 2007, 6(23):2928-2931.

89. Bolós V, Gasent JM, López-Tarruella S, Grande E: The dual kinase complex FAK-Src as a promising therapeutic target in cancer. Onco Targets Ther 2010, 3:83-97.

90. Burnham MR, Bruce-Staskal PJ, Harte MT, Weidow CL, Ma A, Weed SA, Bouton AH: Regulation of c-SRC activity and function by the adapter protein CAS. Mol Cell Biol 2000, 20(16):5865-5878.

91. Chen C-Y, Chang C-Y, Liu H-J, Liao M-H, Chang C-I, Hsu J-L, Shih W-L: Apoptosis induction in BEFV-infected Vero and MDBK cells through Srcdependent JNK activation regulates caspase-3 and mitochondria pathways. Vet Res 2010, 41(2).

92. Di Florio A, Capurso G, Milione M, Panzuto F, Geremia R: Delle Fave G, Sette C: Src family kinase activity regulates adhesion, spreading and migration of pancreatic endocrine tumour cells. Endocr Relat Cancer 2007, 14(1):111-124

93. Götz R: Inter-cellular adhesion disruption and the RAS/RAF and betacatenin signalling in lung cancer progression. Cancer Cell Int 2008, 8(1):7.

94. Liu Y, Gao L, Gelman IH: SSeCKS/Gravin/AKAP12 attenuates expression of proliferative and angiogenic genes during suppression of v-Src-induced oncogenesis. BMC Cancer 2006, 6(1):105.

95. Owen KA, Abshire MY, Tilghman RW, Casanova JE, Bouton AH: FAK Regulates Intestinal Epithelial Cell Survival and Proliferation during Mucosal Wound Healing. PLoS One 2011, 6(8).

96. Tian M, Schiemann W: The TGF- $\beta$ Paradox in Human Cancer: An Update. Future Oncol 2009, 5(2):259-271.

97. Williams SP, Karnezis T, Achen MG, Stacker SA: Targeting lymphatic vesse functions through tyrosine kinases. J Angiogenes Res 2010, 2:13-13. 
98. Liang M, Cai T, Tian J, Qu W, Xie ZJ: Functional characterization of Srcinteracting Na/K-ATPase using RNA interference assay. J Biol Chem 2006, 281:19709-19719.

99. Langenhan JM, Engle JM, Slevin LK, Fay LR, Lucker RW, Smith KR, Endo MM: Modifying the glycosidic linkage in digitoxin analogs provides selective cytotoxins. Bioorg Med Chem Lett 2008, 18(2):670-673.

100. Zhou M, O'Doherty G: The De novo Synthesis of Oligosaccharides Application to the Medicinal Chemistry SAR Study of Digitoxin. Chem/nform Abstract 2008, 39(27).

101. Zhou M, O'Doherty G: The De Novo Synthesis of Oligosaccharides: Application to the Medicinal Chemistry SAR-Study of Digitoxin. Curr Top Med Chem 2008, 8:114-125.

102. Mohammadi $K$, Kometiani $P$, Xie Z, Askari A: Role of protein kinase $C$ in the signal pathways that link $\mathrm{Na}+/ \mathrm{K}+-$ ATPase to ERK1/2. J Biol Chem 2001, 276:42050-42056.

103. Yuan Z: Na/K-ATPase tethers phospholipase $\mathrm{C}$ and IP3 receptor into a calcium-regulatory complex. Mol Biol Cell 2005, 16:4034-4045.

104. Liu L, Askari A: On the importance and mechanism of amplification of digitalis signal through Na+/K+-ATPase. Cell Mol Biol (Noisy-le-Grand) 2006, 52(8):28-30.

105. Kometiani P, Li J, Gnudi L, Kahn BB, Askari A, Xie Z: Multiple signal transduction pathways link $\mathrm{Na}+/ \mathrm{K}+$-ATPase to growth-related genes in cardiac myocytes. The roles of Ras and mitogen-activated protein kinases. J Biol Chem 1998, 273(24):15249-15256.

106. Peng $M$, Huang L, Xie Z, Huang WH, Askari A: Partial inhibition of $\mathrm{Na}+/ \mathrm{K}+$ -ATPase by ouabain induces the Ca2 + -dependent expressions of earlyresponse genes in cardiac myocytes. J Biol Chem 1996, 271(17):10372-10378.

107. Schoner W, Scheiner-Bobis G: Endogenous and exogenous cardiac glycosides: their roles in hypertension, salt metabolism, and cell growth. Am J Physiol Cell Physiol 2007, 293(2):C509-C536.

108. Dueñas-González A, García-López P, Herrera LA, Medina-Franco JL, González-Fierro A, Myrna C: The prince and the pauper. A tale of anticancer targeted agents. Mol Cancer 2008, 7(1):82.

109. Shull MM, Pugh DG, Lingrel JB: Characterization of the human $\mathrm{Na}, \mathrm{K}$ ATPase alpha 2 gene and identification of intragenic restriction fragment length polymorphisms. J Biol Chem 1989, 264(29):17532-17543.

110. Jagielska J, Salquero G, Schieffer B, Bavendiek U: Digitoxin elicits antiinflammatory and vasoprotective properties in endothelial cells: Therapeutic implications for the treatment of atherosclerosis? Atherosclerosis 2009, 206(2):390-396.

111. Srivastava M, Eidelman O, Zhang J, Paweletz C, Caohuy H, Yang Q, Jacobson KA, Heldman E, Huang W, Jozwik $C$, et al: Digitoxin mimics gene therapy with CFTR and suppresses hypersecretion of IL-8 from cystic fibrosis lung epithelial cells. Proc Natl Acad Sci USA 2004, 101(20):7693-7698

112. Yang $Q$, Huang $W$, Jozwik C, Lin $Y$, Glasman M, Caohuy $H$, Srivastava M, Esposito D, Gillette W, Hartley J, et al: Cardiac glycosides inhibit TNFalpha/NF-kappaB signaling by blocking recruitment of TNF receptorassociated death domain to the TNF receptor. Proc Natl Acad Sci USA 2005, 102(27):9631-9636.

113. Bamberger AM, Milde-Langosch $K, R \sqrt{ }$ dssing $E$, Goemann $C, L$ Vaning $T$ : Expression pattern of the AP-1 family in endometrial cancer: correlations with cell cycle regulators. J Cancer Res Clin Oncol 2001, 127(9):545-550.

114. Dumesic PA, Scholl FA, Barragan DI, Khavari PA: Erk1/2 MAP kinases are required for epidermal G2/M progression. J Cell Biol 2009, 185(3):409-422.

115. Karamouzis MV, Konstantinopoulos PA, Papavassiliou AG: The Activator Protein-1 Transcription Factor in Respiratory Epithelium Carcinogenesis. Mol Cancer Res 2007, 5(2):109-120.

116. Crombez L, Morris MC, Dufort S, Aldrian-Herrada G, Nguyen Q, Mc Master G, Coll J-L, Heitz F, Divita G: Targeting cyclin B1 through peptidebased delivery of siRNA prevents tumour growth. Nucleic Acids Res 2009, 37(14):4559-4569.

117. Yuan J, Yan R, Kramer A, Eckerdt F, Roller M, Kaufmann M, Strebhardt K: Cyclin B1 depletion inhibits proliferation and induces apoptosis in human tumor cells. Oncogene 2004, 23(34):5843-5852.

118. Chae SW, Sohn JH, Kim D-H, Choi YJ, Park YL, Kim K, Cho YH, Pyo J-S, Kim JH: Overexpressions of Cyclin B1, cdc2, p16 and p53 in Human Breast Cancer: The Clinicopathologic Correlations and Prognostic Implications. Yonsei Med J 2011, 52(3):445-453.
119. Cooper WA, Kohonen-Corish MRJ, McCaughan B, Kennedy C, Sutherland RL, Lee CS: Expression and prognostic significance of cyclin B1 and cyclin A in non-small cell lung cancer. Histopathology 2009, 55(1):28-36.

120. Egloff AM, Weissfeld J, Land SR, Finn OJ: Evaluation of anticyclin B1 serum antibody as a diagnostic and prognostic biomarker for lung cancer. Ann N Y Acad Sci 2005, 1062:29-40.

121. Kim D-H: Prognostic implications of cyclin B1, p34cdc2, p27(Kip1) and p53 expression in gastric cancer. Yonsei Med J 2007, 48(4):694-700.

122. Wong Y-F, Cheung T-H, Tsao GSW, Lo KWK, Yim S-F, Wang WW, Heung MMS, Chan SCS, Chan LKY, Ho TWF, et al: Genome-wide gene expression profiling of cervical cancer in Hong Kong women by oligonucleotide microarray. Int J Cancer 2006, 118(10):2461-2469.

123. Yoshida T, Tanaka S, Mogi A, Shitara Y, Kuwano H: The clinical significance of Cyclin B1 and Wee1 expression in non-small-cell lung cancer. Ann Oncol 2004, 15(2):252-256.

124. De Souza CP, Ellem KA, Gabrielli BG: Centrosomal and cytoplasmic Cdc2/ cyclin B1 activation precedes nuclear mitotic events. Exp Cell Res 2000, 257(1):11-21.

125. Stark G, Taylor W: Control of the G2/M transition. Mol Biotechnol 2006, 32(3):227-248

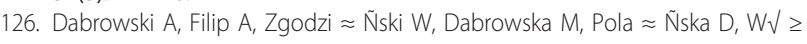
jcik M, Zinkiewicz K, Wallner G: Assessment of prognostic significance of cytoplasmic survivin expression in advanced oesophageal cancer. Folia Histochem Cytobiol 2004, 42(3):169-172.

127. Falleni M, Pellegrini C, Marchetti A, Oprandi B, Buttitta F, Barassi F, Santambrogio L, Coggi G, Bosari S: Survivin gene expression in early-stage non-small cell lung cancer. J Pathol 2003, 200(5):620-626.

128. He L, Hou M, Zhang J, Xu N, Chen P: Subcellular localization of survivin in non-small cell lung cancer. Ai Zheng 2009, 28(9):955-960.

129. Y-j R, Q-y Z: Expression of survivin and its clinical significance in nonsmall cell lung cancer. Beijing Da Xue Xue Bao 2005, 37(5):504-507.

130. Yang H, Fu J-h, Hu Y, Huang W-z, Zheng B, Wang G: Relationship between survivin expression and chemosensitivity of human lung cancer cells. Zhonghua Yi Xue Za Zhi 2007, 87(27):1934-1937.

131. Zhou J-M, Zhou J-H, Deng Z-H, Zheng H, Jiang H-Y, Cao H-Q: Expression of survivin and proliferating cell nuclear antigen in human non-small cell lung cancer. Zhong Nan Da Xue Xue Bao Yi Xue Ban 2005, 30(5):544-548.

132. Beardmore VA, Ahonen LJ, Gorbsky GJ, Kallio MJ: Survivin dynamics increases at centromeres during G2/M phase transition and is regulated by microtubule-attachment and Aurora B kinase activity. J Cell Sci 2004, 117(Pt 18):4033-4042.

133. Beltrami E, Plescia J, Wilkinson JC, Duckett CS, Altieri DC: Acute Ablation of Survivin Uncovers p53-dependent Mitotic Checkpoint Functions and Control of Mitochondrial Apoptosis. J Biol Chem 2004, 279(3):2077-2084.

134. Mita AC, Mita MM, Nawrocki ST, Giles FJ: Survivin: Key Regulator of Mitosis and Apoptosis and Novel Target for Cancer Therapeutics. Clin Cancer Res 2008, 14(16):5000-5005

135. Wolanin K, Piwocka K: Role of survivin in mitosis. Postepy Biochem 2007, 53(1):10-18.

136. Colnaghi R, Wheatley SP: Liaisons between survivin and Plk1 during cell division and cell death. J Biol Chem 2010, 285(29):22592-22604.

137. Lens SMA, Wolthuis RMF, Klompmaker R, Kauw J, Agami R, Brummelkamp T, Kops G, Medema RH: Survivin is required for a sustained spindle checkpoint arrest in response to lack of tension. EMBO J 2003, 22(12):2934-2947.

138. Li F, Ackermann EJ, Bennett CF, Rothermel AL, Plescia J, Tognin S, Villa A, Marchisio PC, Altieri DC: Pleiotropic cell-division defects and apoptosis induced by interference with survivin function. Nat Cell Biol 1999, 1(8):461-466

139. Li F, Ambrosini G, Chu EY, Plescia J, Tognin S, Marchisio PC, Altieri DC: Control of apoptosis and mitotic spindle checkpoint by survivin. Nature 1998, 396(6711):580-584

140. Castedo M, Perfettini J-L, Roumier T, Andreau K, Medema R, Kroemer G: Cell death by mitotic catastrophe: a molecular definition. Oncogene 2004, 23(16):2825-2837.

141. Okada H, Mak TW: Pathways of apoptotic and non-apoptotic death in tumour cells. Nat Rev Cancer 2004, 4(8):592-603.

142. Vakifahmetoglu H, Olsson M, Zhivotovsky B: Death through a tragedy: mitotic catastrophe. Cell Death Differ 2008, 15(7):1153-1162. 
143. Barre' B, Perkins ND: A cell cycle regulatory network controlling NFkappaB subunit activity and function. EMBO J 2007, 26(23):4841-4855.

144. Bartek J, Lukas J: Chk1 and Chk2 kinases in checkpoint control and cancer. Cancer Cell 2003, 3:421-429.

145. Zhou B-BS, Bartek J: Targeting the checkpoint kinases: chemosensitization versus chemoprotection. Nat Rev Cancer 2004, 4(3):216-225.

146. Zhou B-BS, Sausville EA: Drug discovery targeting Chk1 and Chk2 kinases. Prog Cell Cycle Res 2003, 5:413-421.

147. Haas M, Wang H, Tian J, Xie Z: Src-mediated inter-receptor cross-talk between the $\mathrm{Na}+/ \mathrm{K}+-$ ATPase and the epidermal growth factor receptor relays the signal from ouabain to mitogen-activated protein kinases. J Biol Chem 2002, 277:18694-18702.

doi:10.1186/2162-3619-1-4

Cite this article as: Elbaz et al:: Digitoxin and its analogs as novel cancer therapeutics. Experimental Hematology \& Oncology 2012 1:4.

\section{Submit your next manuscript to BioMed Central} and take full advantage of:

- Convenient online submission

- Thorough peer review

- No space constraints or color figure charges

- Immediate publication on acceptance

- Inclusion in PubMed, CAS, Scopus and Google Scholar

- Research which is freely available for redistribution

Submit your manuscript at www.biomedcentral.com/submit 